UDC 004.383.03:621.317.75

DOI: $10.30929 / 2072-2052.2018 .3 .43 .53-59$

\title{
DESIGN AND REALIZATION OF COMPUTER BASED OSCILLOSCOPE USING DSP
}

\section{T. Vince, J. Boško}

Technical University of Košice

Letná, 9, Košice, 042 00, Slovak Republic. E-mail: tibor.vince@tuke.sk, jozef.bosko@student.tuke.sk

Purpose. The design and implementation of a financially affordable computer-based oscilloscope using digital signal controller. Such survey will allow students to study principles of designing, development, programming and operating electronic devices basing on modern microcontroller components. Originality. The paper deals with the research on surveys for development of a low-cost prototype of computer based oscilloscope using modern equipment and technologies. Methodology. The paper proposes one of the possibilities for development computer based oscilloscope using digital signal processor. Authors described whole development process starting from measuring circuit calculations, hardware design, chose and calculation of power conversion elements, development of PCB, development of hardware unit, design and implementation software solutions, oscilloscope calibration and also experimental verification of derived results. Results. In the paper it was described the construction process of a functional oscilloscope, which will serve to measure the electrical voltage using a computer controlled by Nucleo. Computer and Nucleo programs have been designed and created. The programming language $\mathrm{C} \#$ were chosen to create the computer program. The printed circuit board was developed, the individual components were mounted and the whole device was connected. After testing the entire device and calibrating it, additional elements have been added to the software part of the program for the computer. In the future, it is possible to work on improving accuracy or add multiple input channels to measure the electrical voltage or adding the possibility of measuring the current. Practical value. Developed oscilloscope could be used as teaching equipment for students trained in electromechanics. References 11, table 1, figures 12.

Key words: oscilloscope, Nucleo development board, computer control, digital signal processor, PCB.

\section{РОЗРОБКА ТА ВПРОВАДЖЕННЯ КОМП'ЮТЕРИЗОВАНОГО ОСЦИЛОГРАФА НА ОСНОВІ ЦИФРОВОГО СИГНАЛЬНОГО ПРОЦЕСОРА}

\section{Т. Вінсе, Ж. Бошко}

Технічний університет Кошице

Летна, 9, Кошице, 042 00, Словаччина. E-mail: tibor.vince@ @uke.sk, jozef.bosko@ student.tuke.sk

Метою $є$ розробка та впровадження бюджетного варіанту комп’ютеризованого осцилографа на основі цифрового сигнального процесора. Такий підхід дозволить студентам вивчати принципи проектування, розробки, програмування та роботи електронних пристроїв на основі сучасних мікропроцесорних компонентів. У статті наведено результати дослідження підходів щодо створення бюджетного прототипу комп'ютеризованого осцилографа 3 використанням сучасного обладнання i технологій. Пропонується один 3 варіантів розробки комп'ютеризованого осцилографа з використанням цифрового сигнального процесора. Автори описали повний процес розробки, починаючи з розрахунку вимірювальних кіл, проектування апаратного забезпечення, вибору та розрахунку силових перетворювальних елементів, розробки печатної плати, розробки модуля апаратного забезпечення, проектування та впровадження рішень щодо програмного забезпечення, калібрування осцилографа, та закінчуючи експериментальною перевіркою отриманих результатів. У статті описано процес створення функціонального осцилографа, який буде слугувати для вимірювання електричної напруги з використанням комп'ютера, що керується за допомогою плати розробника Nucleo. Було спроектовано і розроблено програми керування, як для персонального комп'ютера, так і для плати Nucleo. Для створення програмного забезпечення персонального комп'ютера було обрано мову програмування С\#. Відповідно до створеного проекту, було створено печатну плату, установлено та під'єднано усі необхідні компоненти. Після тестування усього пристрою та відповідного калібрування, було доопрацьовано програмне забезпечення персонального комп’ютера з метою розширення його функціональних можливостей. У майбутньому планується проведення робіт з поліпшення точності роботи пристрою та додавання додаткових вимірювальних каналів напруги або додавання можливості вимірювання сигналу струму. Розроблений осцилограф може використовуватись як навчальне обладнання для студентів електромеханічних спеціальностей.

Ключові слова: осцилограф, плата розробника Nucleo, комп’ютерне керування, цифровий сигнальний процесор, печатна плата.

PROBLEM STATEMENT. From the first observation of lightning in the sky to the most modern computers, a man was still fascinated by what could the electrical power do. As soon as he came to grips with its strength, he began to create devices that are capable of creating, preserving and exploiting this kind of energy. In the modern times, power instability can cause tremendous damage to sensitive electronics. To determine and modify the power parameters are much more demanding than ever before. Conventional measuring instruments such as voltmeters or ammeter cannot analyze the complex and high frequency frequencies used in today's electronics. For such purposes, oscilloscopes have been developed. These devices deal with signals of various shapes and wide frequency spectra.

EXPERIMENTAL PART AND RESULTS OBTAINED.

Setting the voltage measurement range

Analogue to Digital Converter in Nucleo can operate from $0 \mathrm{~V}$ to $3.3 \mathrm{~V}$. In order to use the oscilloscope in a 
higher voltage range, it will be possible to switch the input measuring range to 5 voltage levels: $\pm 3.3 \mathrm{~V}$; $\pm 12 \mathrm{~V} ; \pm 36 \mathrm{~V} ; \pm 110 \mathrm{~V} ; \pm 350 \mathrm{~V}$. For this reason, an auxiliary circuit is needed to measure input voltages that are several times larger than the input range of the $\mathrm{Nu}$ cleo. At the same time, Nucleo cannot measure the negative voltage, so it is necessary to ensure that the input $\mathrm{AC}$ voltage is adjusted to the way the microcontroller can process.

First, the input voltage will be adjusted by the auxiliary circuit so as to be in the range $0 \mathrm{~V}$ to $3.3 \mathrm{~V}$ or $\pm 1.65 \mathrm{~V}$. For this purpose, the so-called voltage divider, the connection of which is shown in Fig. 1.

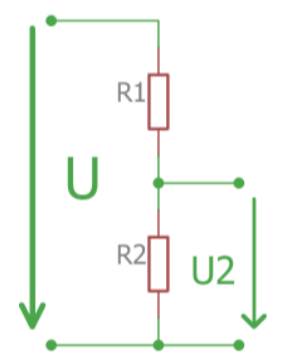

Figure 1 - Power divider

The input voltage $U$ is distributed according to the second Kirchhoff law using the resistors $R_{1}$ and $R_{2}$ at the voltage $U_{1}$ and $U_{2}$. For this application, the $U_{2}$ voltage is substantial. For a practical example, is selected the input voltage ranges $\pm 350 \mathrm{~V}$. To simplify the calculation, maximum absolute voltage values will be taken. The input voltage $U$ will reach a maximum value of $350 \mathrm{~V}$. The output voltage $U_{2}$ has a maximum value of $1.65 \mathrm{~V}$. The resistor parameters $R_{1}$ and $R_{2}$ will be calculated according to the formula:

$$
U_{2}=U \frac{R_{2}}{R_{1}+R_{2}}[\mathrm{~V}],
$$

where $U$ - represents the input voltage; $U_{l}$ - represents the output voltage; $U_{2}$ - represents the output voltage; $R_{1}$ - represents resistor; $R_{2}-$ represents resistor.

After adjustment, the resistor values can be determined as follows:

$$
R_{1}=R_{2}\left(\frac{U}{U_{2}}-1\right)[\Omega] .
$$

The resistor value $R_{2}$ is selected at $10.000 \mathrm{Ohms}$. The value of resistor $R_{l}$ will be further calculated as:

$$
\begin{gathered}
R_{1}=10000\left(\frac{350}{1.65}-1\right) ; \\
R_{1}=2111212.121[\Omega] \cong 2.1[\mathrm{M} \Omega] .
\end{gathered}
$$

The reduction of the input signal amplitude is shown in Fig. 2. The red signal represents the input voltage, the green signal represents the voltage after the adjustment.

Using the voltage divider shown in Fig. 1, the input voltage within $\pm 350 \mathrm{~V}$ was adjusted to a voltage within the range of $\pm 1.65 \mathrm{~V}$. Using the additional circuit shown in Fig. 3, the voltage level will be offset by $+1.65 \mathrm{~V}$. The $3.3 \mathrm{~V}$ pin will be supplied with 3.3 volts of Nucleo, and the GND pin will be connected to the GND Nucleo pin. The output signal between the In pin and the GND pin will acquire values in the range $0 \mathrm{~V}$ to 3.3 V. This offset is shown in Fig. 4. The green signal represents a voltage before the shift of $+1.65 \mathrm{~V}$, the red signal represents the voltage after the shift by $+1.65 \mathrm{~V}$.

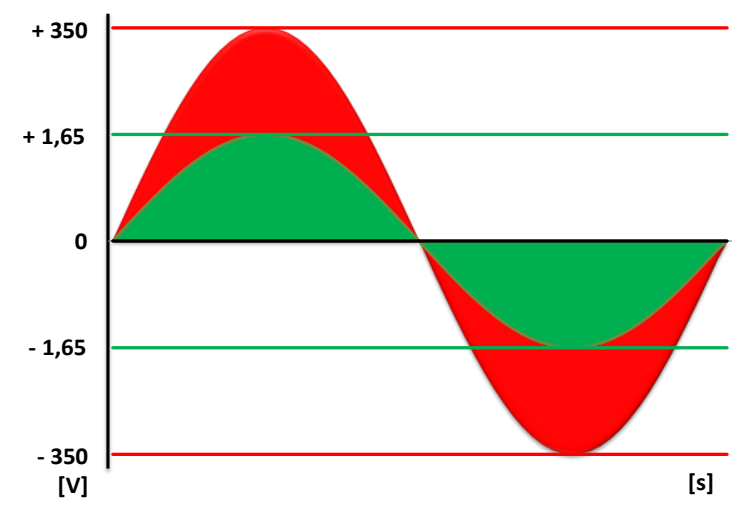

Figure 2 - Reduce the amplitude of the input voltage

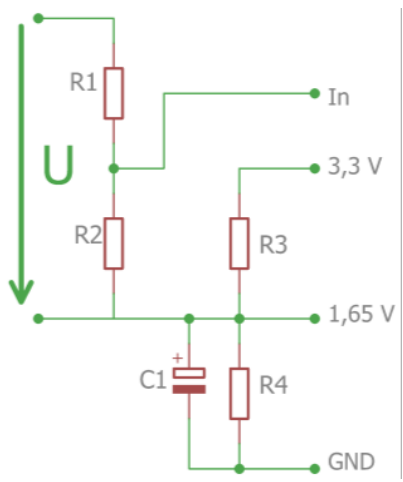

Figure 3 - Zero voltage shifting, diagram

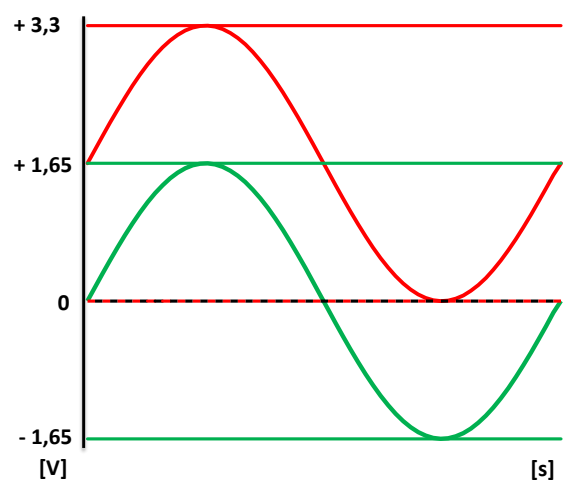

Figure 4 - Zero voltage shifting, graph

As a result of the whole auxiliary circuit, the maximum value of the output voltage $+3.3 \mathrm{~V}$ corresponds to the $+350 \mathrm{~V}$ input signal, $+1.65 \mathrm{~V}$ corresponds to the input signal with a voltage of $0 \mathrm{~V}$ and the signal value $0 \mathrm{~V}$ corresponds to the input signal with a voltage $-350 \mathrm{~V}$. This enables the measurement of the electrical signal within $\pm 350 \mathrm{~V}$ using the Nucleo an analogue to digital converter, which operates from $0 \mathrm{~V}$ to $3.3 \mathrm{~V}$. 
Speed of analogue to digital converter

From a practical measurement, it is found that using a direct memory access, a sampling frequency of approximately $2.9 \mathrm{MHz}$ can be achieved.

Based on the formula:

$$
t_{v}=\frac{1}{f_{p}}=\frac{1}{2900000} \approx 0.3448 \cdot 10^{-6}[\mathrm{~s}],
$$

where $t_{v}$ - represents the time needed to measure one sample; $f_{p}$ - represents the sampling rate of the A / D converter.

One sample of the measured signal will take approximately $0.3448 \cdot 10^{-6} \mathrm{~s}$. When selecting a record of 4096 values, it can be determined that the total time of data collection for this method will be:

$$
t_{c}=4096 \cdot t_{v}=4096 \cdot 0.3448 \cdot 10^{-6} \approx 1.429 \cdot 10^{-3}[\mathrm{~s}],
$$

where $t_{c}$ - represents the total time of data collection in one measurement cycle.

Accordingly, in order to capture at least one whole period during one measurement, the minimum frequency of the input signal may be:

$$
f_{v}=\frac{1}{t_{c}}=\frac{1}{4.429 \cdot 10^{-3}} \approx 699.8[\mathrm{~Hz}],
$$

where $f_{v}$ - represents the frequency of the input signal.

In order for the oscilloscope to be used for lower frequencies, it will be necessary to implement another sampling method, namely the classic conversion of the analog value to digital, without direct memory access. From a practical measurement, it is found that the sampling frequency for this method is approximately $290 \mathrm{kHz}$.

This implementation will use a converter that is already part of the Nucleo. These are three 12-bit converters that are available on sixteen channels. These converters operate in the range of analogue values of $0 \mathrm{~V}$ to $3.3 \mathrm{~V}$. This range corresponds to numerical values ranging from 0 to 4095 [5].

\section{The Nucleo}

STMicroelectronics STM32 Nucleo Development Boards provide an affordable and flexible way for users to try out new ideas and build prototypes with any STM32 microcontroller line, choosing from the various combinations of performance, power consumption, and features.

The Arduino connectivity support and ST Morpho headers make it easy to expand the functionality of the STM32 Nucleo open development platform with a wide choice of specialized shields.

The STM32 Nucleo board does not require any separate probe as it integrates the ST-LINK/V2-1 debugger/programmer. It comes with the STM32 comprehensive software HAL library together with various packaged software examples and direct access to mbed online resources [8].

More common in similar projects is using Arduino microcontrollers, especially Arduino DUE. Arduino now has a wider spread and a very active community, but also the Nucleo series looks so promising. Nucleo board hasn't an external EEPROM memory and even the micro STM32 hasn't an internal EEPROM memory to store permanent variables in case of board reboot, while Arduino can count on Atmel microcontroller EEPROM. In addition, Nucleo lacks of an external power connector in case we want to use shields requesting a power voltage above $5 \mathrm{~V}$ or an external power supply. The comparison between Nucleo board and Arduino DUE is harsher because they mount the same family of microcontrollers (ARM Cortex-M), but the Nucleo has a Cortex-M4 despite of the Cortex-M3 on Arduino DUE and has the floating-point unit too.

So in case you wish to use algorithms that use floating-point heavily, the $\mathrm{C}$ code will be written in the same way on both boards but the compiler for Cortex-M4 will generate far fewer instructions which will be executed quicker and also with significant performance increase in term of low memory footprint. Arduino DUE has a larger number of I/O modules, but those pins can't bear (if configured as input) voltages above $3.3 \mathrm{~V}$, limiting the use of Arduino shields that request $5 \mathrm{~V}$.

Both microcontrollers have the same internal flash memory size as $512 \mathrm{~KB}$. With memory, Sram has the advantage of Nucleo, which has more than a quarter of its memory over ArduinSram. $128 \mathrm{~KB}$ (+ $4 \mathrm{~KB})$ versus 96 KB. Processor speed has a higher Nucleo, $180 \mathrm{MHz}$ versus $84 \mathrm{MHz}$. Both use the 12-bit Analog-Digital Converter and 12-bit Digital-Analogue Converter, with the difference that Nucleo has 3 Analog-Digital Converters.

Developing application for Nucleoonline tool from Arm Mbedavailable at [11] was used. After simple registration, a user's personal account is accessed, where you can simply choose the microcontroller used and all available compatible extensions will be automatically added.

To the data transfer between Nucleo and the computer will serve a serial COM port. Communication will take place in both directions. Nucleo will receive commands from the computer and then send the measured data back to him. Depending on the selected range, Nucleo switches the contacts on the printed circuit board.

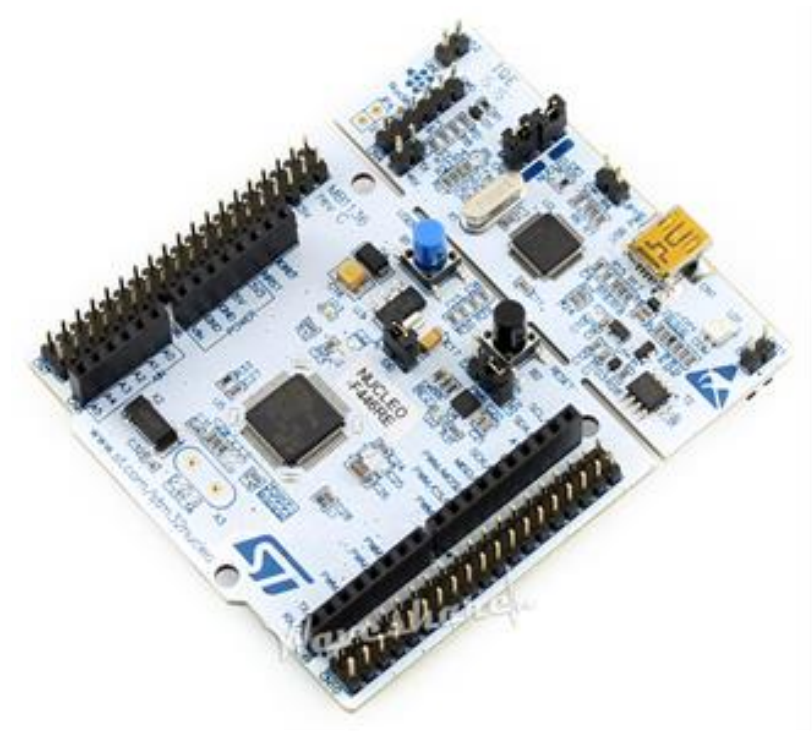

Figure 5 - Measuring circuit diagram 
Upon receipt of the command, the entire measurement is performed and Nucleo sends all the measured values together with the time information as long as the whole measurement was running to the computer.

After a successful measurement of the Nucleo values, a long data chain computer will arrive, which will contain the measurement information and also the measured data.

Display voltage and time rang

The minimum selectable voltage range of the input signal will be within $\pm 3.3 \mathrm{~V}$. For this reason, a minimum range of display is set to $100 \mathrm{mV} / \mathrm{d}$.

The maximum selectable voltage range of the input signal will be within $\pm 350 \mathrm{~V}$. Therefore, the maximum range of display is set to $100 \mathrm{~V} / \mathrm{d}$. The range between $100 \mathrm{mV} / \mathrm{d}$ and $100 \mathrm{~V} / \mathrm{d}$ will be filled in by the following ranges of display: $100 \mathrm{mV} / \mathrm{d} ; 200 \mathrm{mV} / \mathrm{d} ; 500 \mathrm{mV} / \mathrm{d}$; $1 \mathrm{~V} / \mathrm{d} ; 2 \mathrm{~V} / \mathrm{d} ; 5 \mathrm{~V} / \mathrm{d} ; 10 \mathrm{~V} / \mathrm{d} ; 20 \mathrm{~V} / \mathrm{d} ; 50 \mathrm{~V} / \mathrm{d} ; 100 \mathrm{~V} / \mathrm{d}$.

The minimum setting of the time base will be set to $0.5 \mu \mathrm{s} / \mathrm{d}$. The maximum will be $10 \mathrm{~ms} / \mathrm{d}$. When distributing a 10-piece oscilloscope in the time range, this range will allow a $100 \mathrm{~ms}$ signal to be fused. This corresponds to one input signal period of $10 \mathrm{~Hz}$. The range between $0.5 \mu \mathrm{s} / \mathrm{d}$ and $10 \mathrm{~ms} / \mathrm{d}$ will be filled by the following ranges: $0.5 \mu \mathrm{s} / \mathrm{d} ; 1 \mu \mathrm{s} / \mathrm{d} ; 2 \mu \mathrm{s} / \mathrm{d} ; 5 \mu \mathrm{s} / \mathrm{d} ; 10 \mu \mathrm{s} / \mathrm{d}$; $20 \mu \mathrm{s} / \mathrm{d} ; 50 \mu \mathrm{s} / \mathrm{d} ; 100 \mu \mathrm{s} / \mathrm{d} ; 200 \mu \mathrm{s} / \mathrm{d} 500 \mu \mathrm{s} / \mathrm{d} ; 1 \mathrm{~ms} / \mathrm{d}$; $2 \mathrm{~ms} / \mathrm{d} ; 5 \mathrm{~ms} / \mathrm{d} ; 10 \mathrm{~ms} / \mathrm{d}$.

\section{Production of DPS}

As mentioned above, this work will be able to switch the input voltage ranges. Specific ranges are selected at: $\pm 3.3 \mathrm{~V} ; \pm 12 \mathrm{~V} ; \pm 36 \mathrm{~V} ; \pm 110 \mathrm{~V} ; \pm 350 \mathrm{~V}$

Calculated and selected resistor values are presented in Tabl. 1.

Table 1 - Values of voltage dividers resistors

\begin{tabular}{|l|r|r|}
\hline $\begin{array}{c}\text { Range } \\
{[\mathrm{V}]}\end{array}$ & $\begin{array}{r}\text { CalculatedValue } \\
{[\Omega]}\end{array}$ & Selectedvalue $[\Omega]$ \\
\hline \pm 3.3 & 10000 & 10000 \\
\hline \pm 12 & 62727 & 68000 \\
\hline \pm 36 & 208182 & 220000 \\
\hline \pm 110 & 656667 & 680000 \\
\hline \pm 350 & 2111212 & 2200000 \\
\hline
\end{tabular}

Selecting higher values also ensures that the input range is somewhat larger than calculated, thus providing a voltage reserve.

Extension relays that are commonly available to $\mathrm{Ar}$ duino microcontrollers will be used to switch ranges. These extensions work on the principle of switching the relay by switching on the transistor. Switching between five ranges will require an extension that includes 4 relay and one extension that includes one relay.

Wiring diagram is displayed on Fig. 6.

Where components values are followed:

$R_{15}=10 \mathrm{k} \Omega, R_{14}=68 \mathrm{k} \Omega, R_{13}=220 \mathrm{k} \Omega$, $R_{12}=680 \mathrm{k} \Omega, R_{11}=2,2 \mathrm{M} \Omega, R_{2}=10 \mathrm{k} \Omega, R_{3}=1 \mathrm{M} \Omega$ Trimer, $R_{4}=480 \mathrm{k} \Omega, C_{l}=10 \mu \mathrm{F}$, Relay module $1 \mathrm{x}=\mathrm{SRD}-$ 05VDC $-\mathrm{SL}-\mathrm{C}$, Relay module $4 \mathrm{x}=\mathrm{JQC}-3 \mathrm{FF}-\mathrm{S}-\mathrm{Z}$, Nucleo $=\mathrm{F} 446 \mathrm{RE}$.

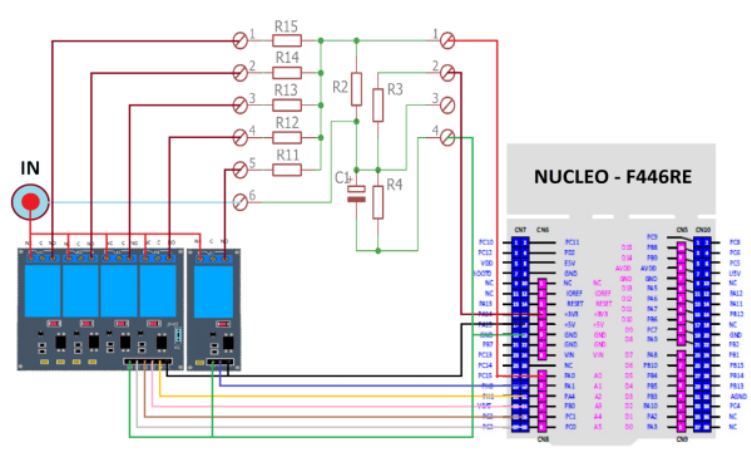

Figure 6-Measuring circuit diagram

In the manufacture of this printed circuit board, the ironing method was used. For the ironing method, the mirror must be reversed (Fig. 7) and printed using a laser printer. It is advisable to print in the best possible quality as the printer allows (in this case 1200 dpi print quality).

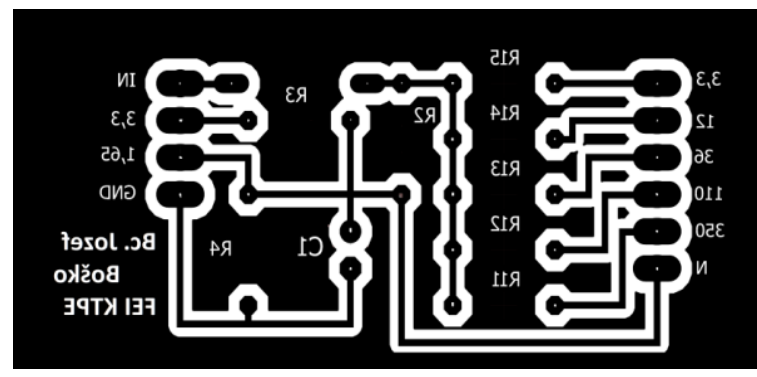

Figure 7 - Template for PCB production

The copper plate was adjusted to the required dimensions, roughened with fine abrasive paper and cleaned with a solution of alcohol and acetone which was mixed in a 3:1 ratio. After aligning the edges, an iron was attached to the paper. Thoroughly ironed the paper with the cruel movements. Ironing took approximately 1 to 2 minutes. After complete cooling, the board was immersed in warm water for several minutes. The paper was separated and only the toner from the printer remained on the copper layer. For this purpose, a solution of ferric chloride $\left(\mathrm{FeCl}_{3}\right)$ and water was used in a ratio of 0.5 kilograms of ferric chloride to 1 liter of water. The plate was immersed in this solution for about 15 to 20 minutes. After it was finished, the board could be washed and cleaned. Created raw PCB is shown in Fig. 8.

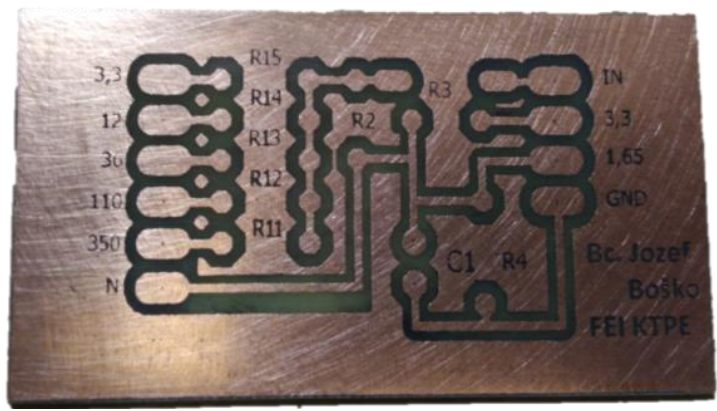

Figure $8-\mathrm{PCB}$ 
Subsequently, holes were drilled onto the board and fitted with prepared parts according to the wiring diagram.

All components: relay modules, circuit board and Nucleo were mounted in the box. In it, holes were drilled to connect the oscilloscope and data wire connector to connect to the computer. The individual elements were fastened by screws to the bottom of the box. Resulting components installation is shown in Fig. 9.

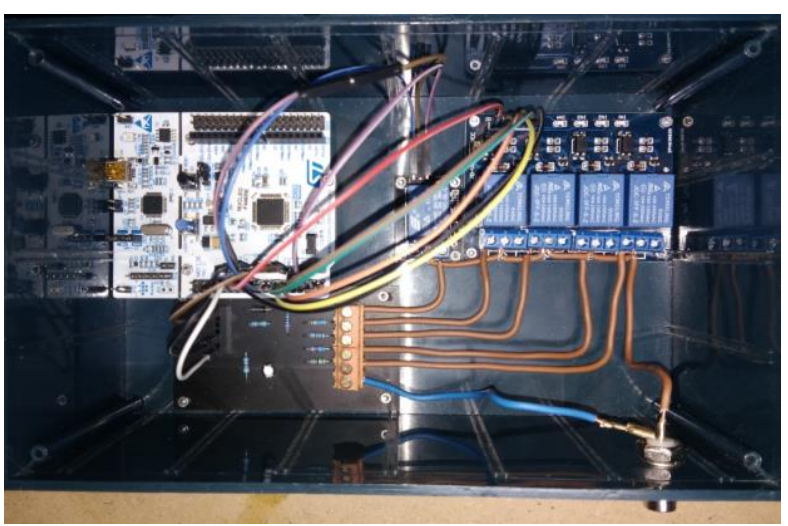

Figure 9 - Resulting components installation

Final covered realized device is shown in Fig. 10.

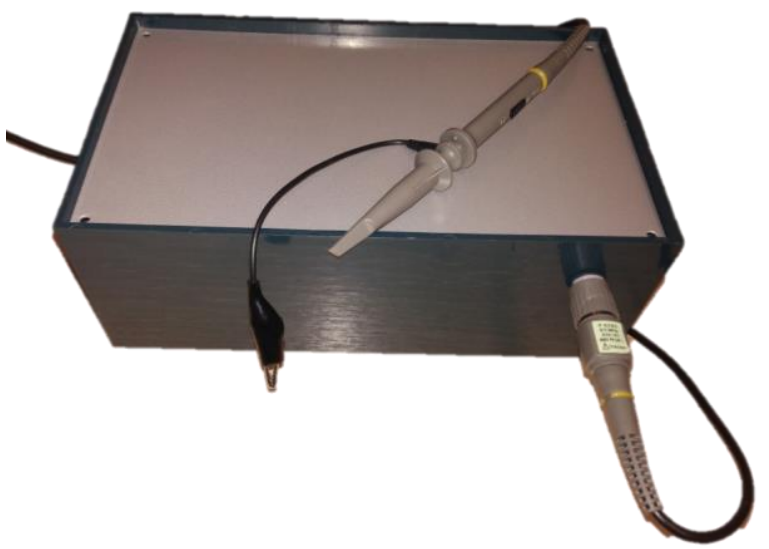

Figure 10 - Final device design

3 sampling modes are selected. Each of these modes will provide measurement within a certain frequency range:

1) mode One, using DMA, achieves a maximum sampling rate of approximately $2,9 \mathrm{MHz}$;

2) mode two uses simple analog value conversion to digital using read_u16(). This mode achieves a maximum sampling frequency of approximately $290 \mathrm{kHz}$;

3) mode three uses the same function as mode two, with a time delay of $40 \mu \mathrm{s}$ between each shift. At this delay, the sampling frequency is approximately $23 \mathrm{kHz}$.

Based on the calculations in $3^{\text {rd }}$ chapter, it is possible to determine the frequency ranges of the periodic input signal for each mode. When observing the sampling of at least 5 samples per input signal period, the ranges are as follows:

Mode 1 can be used for the frequency range from $700 \mathrm{~Hz}$ to $580 \mathrm{kHz}$;

Mode 2 can be used for the frequency range from
$70 \mathrm{~Hz}$ to $58 \mathrm{kHz}$;

Mode 3 can be used for the frequency range from $6 \mathrm{~Hz}$ to $4,6 \mathrm{kHz}$.

Every mode can be used to measure a single input signal. However, mode 3 is recommended, since the longest time of the input signal is measured in this mode.

Application for oscilloscope in C\#

Due to previous experience, the $\mathrm{C} \#$ programming language and the Microsoft Visual Studio programming environment were selected. Microsoft Visual Studio is an environment that offers high variability in program and graphic design applications, and since it is provided directly from Microsoft, compatibility with practically all Microsoft operating systems is ensured.

Communication uses simple commands composed of individual characters. These commands can be divided into two groups. The characters "D", "A", "U" define the sampling rate. The characters "1", "2", "3", "4", "5" define the range of input voltage to be used. Sending the "D" command, enters the Nucleo measurement request in the fastest sampling mode - Mode One. The "A" command, enters the measurement request in the second sampling rate mode, and the "U" command, enters the request to use the third, slowest sampling mode.

Command "1" enters a command to change the range on the printed circuit board to $\pm 3.3 \mathrm{~V}$. Command "2" specifies a range switching command to $\pm 12 \mathrm{~V}$. "3" commands to switch the range to $\pm 36 \mathrm{~V}$. "4" inputs a range switching command to $\pm 110 \mathrm{~V}$ and command "5"specifies a switching command to $\pm 350 \mathrm{~V}$.

The computer receives from Nucleo a long string that will contain the following parameters: (control character); (sampling rate); (input voltage range); (time of measurement); (samples); (control character).

All of these data are separated by ";". The data will be divided into a string array using the recvData.Split (';') function. These data will then be divided according to their definition. Control characters, sampling rate, and input voltage range will be stored in positive numerical integer variables (UInt16). The time value will be stored in the positive numeric integer variable (UInt32), and the individual values will be stored in a numeric floating point field (float [J). The values that the computer itself receives are integer values after performing the Analog to Digital Converter conversion. As they will continue to work with them and then be converted to a specific voltage value, the format (float []) is selected.

When determining the analog value of the input voltage from the measured numerical value, it is necessary to start from the theory described in $2^{\text {nd }}$ chapter. Since the input voltage zero is offset by $+1.65 \mathrm{~V}$, it is necessary to subtract the numerical value 2048 from the measured value. This value represents $1.65 \mathrm{~V}$ converted to digital. This adjustment gives the actual polarity of the individual records corresponding to the instantaneous input voltage values. Subsequently, according to the selected voltage range, it is possible to transfer this digital value to the corresponding value of the input electric voltage.

Required display and calculated input signal pa- 
rameters are:

- maximum voltage of the measured input signal;

- minimum voltage of the measured input signal;

- middle value of the measured signal;

- frequency of measured signal;

- Fourier transform of the measured signal.

There are two ways to store measured data. The first way is to store numeric values in a text file. The second is the graphical layout of Figs. Both methods are available for the time course of the input signal even for the calculated Fourier transform. When saving, you can choose any storage location on your computer.

Two methods are available to calibrate the oscilloscope. The first method provides software calibration. When the oscilloscope probe is disconnected, you can click the Calibration button. This ensures that the resulting deviation from the zero value (the mean value of the voltage) is stored in a floating point numeric variable. This deviation will be taken into account for every further measurement in the currently selected range. With this method, it is necessary to take into account that the feed is realized only by software, and therefore at a high value of this feed, the voltage at the analogue input of the $\mathrm{Nu}$ cleo can be less than $0 \mathrm{~V}$ or greater than $3.3 \mathrm{~V}$ at the selected range. The values can damage the entire device. Therefore, there is also a second calibration option available, namely hardware calibration. For this purpose a resistor with variable resistance $R_{3}$ (trimer) is used. Changing the value of this resistance will change the ratio of the voltage divider formed by elements $R_{3}$ and $R_{4}$. By adjusting this ratio, it is possible to set a zero value of the output signal. Verification can be done directly by the oscilloscope itself. For the need for a more accurate zero setting, you need to connect the voltmeter between the IN and GND pins on the printed circuit board. When the voltage is set to $1.65 \mathrm{~V}$, the device is properly calibrated. Main application window is shown in Fig. 11.

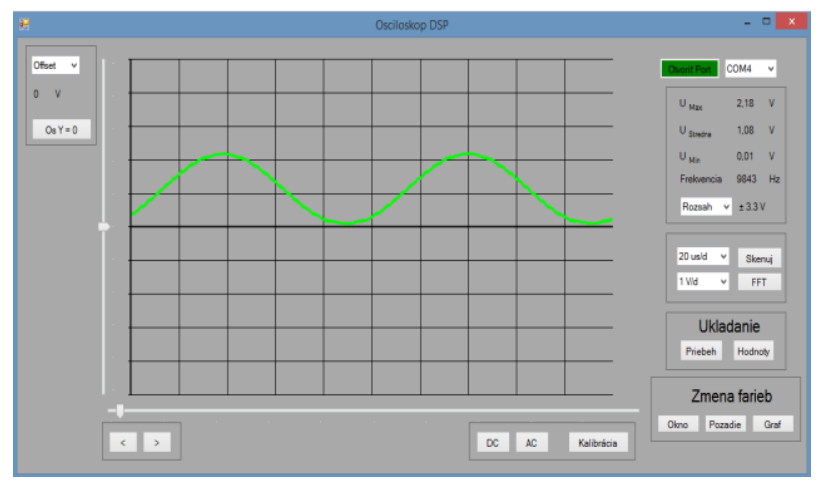

Figure 11 - Main window screenshot

The application is able to calculate Fast Fourier Transformation (FFT) from measured signal. For such a calculation MathNet library is used. Window with FFT graph is shown in Fig. 12.

Create oscilloscope application supports export measured and also calculated (FFT) data - as pictures (png) or values (csv) form. Measured data could be displayed with different time base. The application supports many other functions common for oscilloscope.

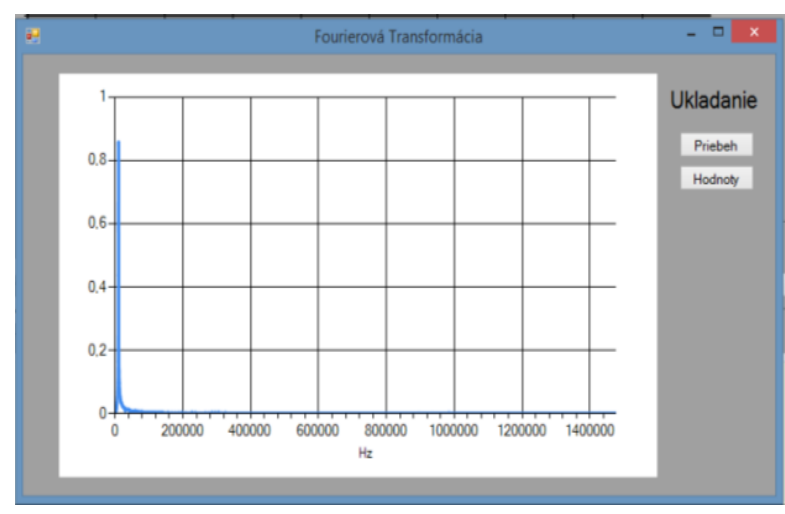

Figure 12 - Calculated FFT

CONCLUSIONS. The aim of this project was construct a functional oscilloscope, which will serve to measure the electrical voltage using a computer controlled by Nucleo. Computer and Nucleo programs have been designed and created. The programming language $\mathrm{C}$ \# were chosen to create the computer program. The printed circuit board was created, the individual components were mounted and the whole device was connected. After testing the entire device and calibrating it, additional elements have been added to the software part of the program for the computer. In the future, it is possible to work on improving accuracy or add multiple input channels to measure the electrical voltage or adding the possibility of measuring the current.

\section{ACKNOWLEDGEMENT.}
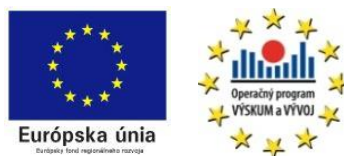

We support research activities in Slovakia / Project is co-financed

from EU funds. This paper was developed within the Project "Centre of Excellence of the Integrated Research \& Exploitation the Advanced Materials and Technologies in the Automotive Electronics ", ITMS 26220120055

\section{REFERENCES}

1. Mylms portal: Děličnapětízatížený a nezatížený, available at: https://www.mylms.cz/text-3-delic-napetizatizeny-a-nezatizeny (accessed March 07, 2018)

2. Nucleo-F446RE, (Illustration picture), available at: http://www.electronicaplugandplay.com/components /com_mijoshop/opencart/image/cache/catalog/sistemas_ embebidos/N\%C3\%BAcleo_FR446RE/STM32F446RE \%20WEB4-500x500.jpg (accessed April 16, 2018)

3. 4 Relay Module (Illustration picture), available at: http://microcontrollerslab.com/wp-content/uploads/ 2016/10/Relay-module-for-arduino.jpg ～(accessed April 22, 2018)

4. Numerics portal. Math.NET Numerics, available at: https://numerics.mathdotnet.com/ (accessed April 22, 2018)

5. Board: Nucleo F446RE, available at: https://github.com/RIOT-OS/RIOT/wiki/Board:- 
Nucleo-F446 (accessed May 09, 2018)

6. Kováč, D., Kováčová, I. and Molnár, J. (2009), "Elektromagnetic compatibility - measurement", Published by TU FEI, Košice, ISBN 978-80-553-0151-8.

7. Guzan, M., Špaldonová, D., Hodulíková, A., Tomčíková, I. and Gladyr, A. (2011), "Boundary Surface and Load Plane of the Ternary Memory", Electromechanical and energy saving systems, Vol. 15, no. 3, pp. 163-167. ISSN 2072-2052

8. Emcu, How to use NUCLEO-F401RE and Mbed

NUCLEO, available at: http://www.emcu.it/NUCLEO
evaBoards/HowToUse-NUCLEO-F401RE.pdf (accessed March 03, 2017)

9. Dziak, J. and Tomčíková, I. (2016), "Models of ideal linear elements of $\mathrm{DC}$ and $\mathrm{AC}$ circuits and circuit simulation in MATLAB using Sparse Tableau analysis", SSIEE, Vol. 5, Košice, pp. 139-141. ISBN 978-80-553-2569-9

10. arm MBED. Arm Mbed OS developer site Mbed OS 5, available at: https://os.mbed.com/ (accessed April 19, 2018)

\section{РАЗРАБОТКА И ВНЕДРЕНИЕ КОМПЬЮТЕРИЗИРОВАННОГО ОСЦИЛЛОГРАФА НА ОСНОВЕ ЦИФРОВОГО СИГНАЛЬНОГО ПРОЦЕССОРА}

\section{Т. Винсе, Ж. Бошко}

Технический университет Кошице

Летна, 9, Кошице, 042 00, Словакия. E-mail: tibor.vince@tuke.sk, jozef.bosko@student.tuke.sk

Цель работы - разработка и внедрение бюджетного варианта компьютеризированного осциллографа на основе цифрового сигнального процессора. Такой подход позволит студентам изучать принципы проектирования, разработки, программирования и работы электронных устройств на основе современных микропроцессорных компонентов. Приведены результаты исследования подходов к созданию бюджетного прототипа компьютеризированного осциллографа с использованием современного оборудования и технологий. В статье предлагается один из вариантов разработки компьютеризированного осциллографа с использованием цифрового сигнального процессора. Авторы описали полный процесс разработки, начиная с расчета измерительных цепей, проектирование аппаратного обеспечения, выбора и расчета силовых преобразовательных элементов, разработки печатной платы, разработки модуля аппаратного обеспечения, проектирование и внедрение решений по программному обеспечению, калибровки осциллографа, и заканчивая экспериментальной проверкой полученных результатов. В статье описан процесс создания функционального осциллографа, который будет служить для измерения электрического напряжения с использованием компьютера, управляемого с помощью платы разработчика Nucleo. Были спроектированы и разработаны программы управления как для персонального компьютера так и для платы Nucleo. Для создания программного обеспечения персонального компьютера был выбран язык программирования С\#. В соответствие с созданным проектом, была реализована печатная плата, установлены и подключены все необходимые компоненты. После тестирования всего устройства и соответствующей калибровки, было доработано программное обеспечение персонального компьютера с целью расширения его функциональных возможностей. В будущем планируется проведение работ по улучшению точности работы устройства и добавления дополнительных измерительных каналов напряжения или добавления возможности измерения сигнала тока. Разработанный осциллограф может использоваться как учебное оборудование для студентов электромеханических специальностей.

Ключевые слова: осциллограф, плата разработчика Nucleo, компьютерное управление, цифровой сигнальный процессор, печатная плата.

Стаття надійшла 11.08.2018. 